\title{
PENGARUH PEMBERIAN AEROBIK EXERCISE TERHADAP SINDROM METABOLIK PADA WANITA DEWASA DI KOTA BANDA ACEH
}

\author{
Nunung Sri Mulyani, Andriani, Wiqayatun Khazanah \\ Jurusan Gzi Politeknik Kesehatan Kemenkes Aceh Jln. Soekarno-Hatta, Lampeunerut. Aceh Besar. Telp: 065146121. \\ E-mail: nunungmulyani76@gmail.com
}

\begin{abstract}
ABSTRAK
Latar Belakang : Data epidemiologi menyebutkan prevalensi sindroma metabolik dunia adalah 20-25\%. Dari data Himpunan Studi Obesitas Indonesia (HISOBI) menunjukkan prevalensi Sindrom metabolik sebesar 13,13\%. Komponen utama sindrom metabolik diantaranya adalah obesistas abdomen, peningkatan kadar glukosa darah (sewaktu dan atau puasa), peningkatan tekanan darah dan dislipidemia. Diabetes mellitus, obesitas sentral, dislipidemia, dan hipertensi merupakan komponen sindrom metabolik sehingga peningkatan prevalensinya akan berpengaruh pada peningkaan kejadian sindrom metabolik. Adapun salah satu faktor yang dapat menurunkan sindrom metabolik adalah dengan melakukan aktivitas fisik salah satunya dengan aerobic exercise.

Metode : Penelitian ini dilakukan pada bulan April s/d Oktober 2016. Desain penelitian yang digunakan adalah quasi eksperimen dengan pendekatan prepostest observational, untuk mengkaji pemberian aeobic exercise terhadap sindrom metabolik pada wanita dewasa.

Hasil : Sebelum diberikan aerobic exercise rata-rata lingkar pinggang sebesar 81,28 cm, tekanan darah sistolik sebesar 133,28 $\mathrm{mmHg}$ dan diastolic sebesar 87,44 mmHg serta kadar gula darah sebesar 110,52 $\mathrm{mg} / \mathrm{dl}$. Setelah diberikan aerobic exercise rata-rata lingkar pinggang sebesar 80,56 cm, tekanan darah sistolik sebesar 131,58 $\mathrm{mmHg}$ dan diastolic sebesar 85,44 mmHg serta kadar gula darah sebesar 107,04 $\mathrm{mg} / \mathrm{dl}$.
\end{abstract}

Kesimpulan : Ada pengaruh pemberian aerobic exercise terhadap lingkar pinggang $(p=0,00)$, tekanan darah $(p=0,00)$ dan kadar gula darah $(p=0,00)$

Kata Kunci: Aerobik exercise, Sindrom metabolik

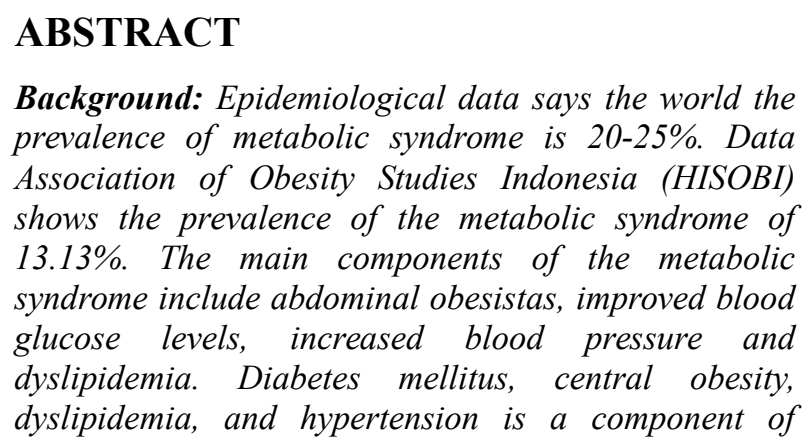

metabolic syndrome so that the increase in prevalence would affect the peningkaan incidence of metabolic syndrome. The one factor that can decrease the metabolic syndrome is to perform physical activity one with aerobic exercise.

Methods: This research will be conducted in April s / d Oktober 2016. The research design is quasiexperimental with pre-posttest observational approach, to assess aeobic granting exercise of the metabolic syndrome in adult women.

Results: Before the aerobic exercise was given an average of $81.28 \mathrm{~cm}$ waist circumference, systolic blood pressure of $133.28 \mathrm{mmHg}$ and diastolic by $87.44 \mathrm{mmHg}$ and the blood sugar levels of $110.52 \mathrm{mg} / \mathrm{dl}$. After the aerobic exercise was given an average of $80.56 \mathrm{~cm}$ waist circumference, systolic blood pressure of 131.58 $\mathrm{mmHg}$ and diastolic by $85.44 \mathrm{mmHg}$ and the blood sugar levels of $107.04 \mathrm{mg} / \mathrm{dl}$.

Conclusion: There is the effect of aerobic exercise on waist circumference $(p=0.00)$, blood pressure $(p=$ $0.00)$ and blood sugar levels $(p=0.00)$

Keywords: Aerobic exercise, metabolic syndrome

\section{PENDAHULUAN}

Data epidemiologi menyebutkan prevalensi sindroma metabolik dunia adalah 20-25\%. Menurut Cammeron, hasil penelitian di Perancis menemukan prevalensi sindroma metabolik sebesar $23 \%$ pada pria dan $21 \%$ pada wanita.1 Prevalensi sindrom metabolik pada populasi masyarakat perkotaan di China yaitu $14 \%$ - $16 \%$ dan secara terus menerus mengalami peningkatan.2 Dari data Himpunan Studi Obesitas Indonesia (HISOBI) menunjukkan prevalensi SM sebesar 13,13\%.3 Berdasarkan penelitian yang dilakukan oleh National Cholesterol Education Program Adult Treatment Panel III (NCEP-ATP III), diketahui bahwa prevalensi sindroma metabolik pada laki-laki lebih besar daripada perempuan, yaitu 9,1\% dibanding 3,7\%.4 Di Indonesia penelitian mengenai prevalensi sindrom metabolik sangat bervariasi di RSUD 
Dr. Soetomo Surabaya didapatkan bahwa dari 100 orang, 31\% memenuhi kriteria menderita sindrom metabolik.6 Pada penelitian yang dilakukan oleh Dwipayana, dkk, didapatkan prevalensi sindroma metabolik sebesar $18,2 \%$.7 Pada penelitian ini ternyata lebih banyak pada wanita. Prevalensinya semakin meningkat dengan bertambahnya usia, dan didapatkan bahwa komponen sindroma metabolik yang terbanyak adalah obesitas sentral. Di Makassar dilaporkan pada sebuah studi yang dilakukan John Adam M.F, dari 227 pria berumur 21-81 tahun, 55,4\% memenuhi keriteria sindrom metabolik, kelompok usia 46-55 tahun yakni $35,9 \%,<35$ tahun yang menderita sindrom metabolik ditemukan sama dengan yang ada pada negara maju. 8

Diabetes mellitus, obesitas sentral, dislipidemia, dan hipertensi merupakan komponen sindrom metabolik sehingga peningkatan prevalensinya akan berpengaruh pada peningkaan kejadian sindrom metabolik.9

Data Riskesdas 2007 menunjukkan bahwa prevalensi penduduk Indonesia untuk diabetes mellitus sebesar $1,1 \%$, penyakit jantung sebesar $0,9 \%$, hipertensi yaitu $7,6 \%$, dan obesitas sentral yaitu 18,8\%.9 Berdasarkan Riskesdas 2013, terdapat peningkatan pada diabetes mellitus menjadi $2,1 \%$, obesitas sentral menjadi $26,6 \%$, hipertensi menjadi $9,5 \%$, dan penyakit jantung meningkat menjadi $1,5 \% .10$

Sindroma metabolik merupakan kumpulan kelainan metabolik komplek yang muncul sebagai faktor risiko penyakit kardiovaskular serta diabetes mellitus tipe II. Komponen utama sindrom metabolik diantaranya adalah obesistas abdomen, peningkatan kadar glukosa darah (sewaktu dan atau puasa), peningkatan tekanan darah dan dislipidemia. 11

Kriteria sindrom metabolik terdiri dari hipertensi, tingginya kadar trigliserida, rendahnya kadar HDL kolesterol, tingginya kadar glukosa puasa serta obesitas sentral melalui pengukuran lingkar pinggang. Obesitas sentral di sini akan didapatkan lebih banyak asam lemak bebas yang akan menyebabkan terjadinya resistensi insulin, yang secara berkelanjutan dapat mengakibatkan terjadinya peningkatan trigliserida serta penurunan HDL kolesterol.12

Tekanan darah dan kadar glukosa darah merupakan bagian dari komponen diagnostik sindrom metabolik yang paling mudah untuk digunakan untuk screening awal sindrom metabolik, khususnya bagi mereka yang mengalami obesitas abdominal. Tekanan darah maupun glukosa dalam darah erat kaitannya dengan asupan energi serta aktivitas fisik.13

Aktivitas fisik yang cukup dapat menurunkan tekanan darah sistolik bagi individu prehipertensi maupun hipertensi. Bagi seseorang yang melakukan aktivitas fisik dengan intensitas sedang hingga tinggi dengan frekuensi serta durasi yang teratur mempunyai perbedaan signifikan dalam penurunan risiko penyakit kardiovaskular serta mempunyai tekanan darah yang lebih rendah.14

\section{DESAIN PENELITIAN}

Penelitian ini merupakan penelitian yang bersifat quasi eksperimen dengan pendekatan pre-post test observasional, yaitu untuk mengkaji pemberian aktivitas fisik (aerobic exercise) terhadap sindrom metabolik pada wanita dewasa. Penelitian ini dilakukan pada bulan April s/d Oktober 2016 yang bertempat di kota Banda Aceh. Populasi dalam penelitian ini adalah semua wanita dewasa dengan kategori sindrom metabolik. Sampel pada penelitian ini adalah wanita dewasa dengan kategori sindrom metabolic yang ada di klub senam Ellan dengan jumlah sampel sebanyak 25 orang. Pengambilan sampel dilakukan dengan cara purposive sampling. Analisis dan pengolahan data menggunakan perangkat SPSS berdasarkan analisis univariat dan bivariat.

\section{HASIL DAN PEMBAHASAN}

\section{Karakteristik Sampel}


Tabel 1. Rata-rata Umur, Berat Badan dan Tinggi Badan Sampel Penelitian

\begin{tabular}{l|c|c|c|c|c}
\hline Variabel & n & Mean & $\begin{array}{c}\text { St. } \\
\text { Deviasi }\end{array}$ & Max & Min \\
\hline Umur & 25 & 37,52 & 5,092 & 50 & 30 \\
BB (kg) & 25 & 64,56 & 6,820 & 75 & 55 \\
TB (cm) & 25 & 155,84 & 4,625 & 165 & 150 \\
\hline
\end{tabular}

Dari tabel 1 diketahui bahwa rata-rata usia sampel adalah 37,52 tahun, berat badan sampel rata-rata adalah $64,56 \mathrm{~kg}$ dan tinggi badan sampel rata-rata adalah $155,84 \mathrm{~cm}$.

\section{Rata-rata Lingkar pinggang, Tekanan} darah dan Kadar gula darah sebelum pemberian aerobic exercise

Tabel 2. Rata-rata Lingkar pinggang, Tekanan darah dan Kadar gula darah sebelum pemberian aerobic exercise

\begin{tabular}{l|c|c|c|c|c}
\hline \multicolumn{1}{c|}{ Variabel } & $\mathbf{n}$ & Mean & $\begin{array}{c}\text { St. } \\
\text { Deviasi }\end{array}$ & Max & Min \\
\hline $\begin{array}{l}\text { Lingkar } \\
\text { pinggang }\end{array}$ & 25 & 81,28 & 1,16 & 84,1 & 80,0 \\
Sistolik & 25 & 133,28 & 3,02 & 140 & 130 \\
Diastolik & 25 & 87,44 & 2,25 & 92 & 85 \\
KGD & 25 & 110,52 & 9,07 & 125 & 100 \\
\hline
\end{tabular}

Dari tabel 2 diketahui bahwa sebelum aerobic exercise di dapatkan rata-rata lingkar pinggang sebesar 81,28 , tekanan darah sistolik sebesar 133,28 dan diastolic sebesar 87,44, serta kadar gula darah sebesar 110,52

3. Rata-rata Lingkar pinggang, Tekanan darah dan Kadar gula darah sesudah pemberian aerobic exercise
Tabel 3. Rata-rata Lingkar pinggang, Tekanan darah dan Kadar gula darah sesudah pemberian aerobic exercise

\begin{tabular}{l|l|l|l|l|l}
\hline Variabel & $\mathbf{n}$ & Mean & $\begin{array}{c}\text { St. } \\
\text { Deviasi }\end{array}$ & Max & Min \\
\hline $\begin{array}{l}\text { Lingkar } \\
\text { pinggang }\end{array}$ & 25 & 80,56 & 0,93 & 83,0 & 79,0 \\
Sistolik & 25 & 131,58 & 2,32 & 138 & 129 \\
Diastolik & 25 & 85,44 & 3,09 & 90 & 81 \\
KGD & 25 & 107,4 & 6,93 & 121 & 99 \\
\hline
\end{tabular}

Dari tabel 3 diketahui bahwa sesudah aerobic exercise di dapatkan rata-rata lingkar pinggang sebesar 80,56 , tekanan darah sistolik sebesar 131,58 dan diastolic sebesar 85,44, serta kadar gula darah sebesar 107,4.

\section{Pengaruh Aerobic Exercise terhadap lingkar pinggang, tekanan darah dan kadar gula darah pada wanita dewasa}

Tabel 4. Pengaruh Aerobic Exercise terhadap lingkar pinggang, tekanan darah dan kadar gula darah pada wanita dewasa yang sindrom metabolic

\begin{tabular}{l|c|c|c|c}
\hline Variabel & $\mathbf{n}$ & Mean \pm SD & T & $\begin{array}{c}\boldsymbol{p} \\
\text { alu } \\
\end{array}$ \\
& & & & $\boldsymbol{e}$ \\
\hline LP & 25 & $0,72 \pm 0,62$ & 5,81 & 0,00 \\
Sistolik & 25 & $1,70 \pm 1,24$ & 6,84 & 0,00 \\
Diastolik & 25 & $2,00 \pm 1,73$ & 5,77 & 0,00 \\
KGD & 25 & $3,48 \pm 5,80$ & 2,99 & 0,00 \\
\hline
\end{tabular}


Dari tabel 4 setelah dilakukan uji statistic T-test dependen didapatkan bahwa ada pengaruh Aerobic Exercise terhadap lingkar pinggang $(\mathrm{p}=0,00)$, tekanan darah $(\mathrm{p}=0,00)$ dan kadar gula darah $(\mathrm{p}=0,00)$.

\section{PEMBAHASAN}

\section{Pengaruh Aerobic Exercise terhadap lingkar pinggang pada wanita dewasa yang sindrom metabolik}

Berdasarkan hasil penelitian setelah dilakukan uji statistic T-test dependent pada table 5 didapatkan bahwa ada pengaruh aerobic exercise terhadap lingkar pinggang $(p=0,00)$. Rata-rata lingkar pinggang sebelum perlakuan sebesar 81,28 dan setelah perlakuan selama 4 minggu lingkar pinggang menjadi 80,56. Jadi berdasarkan penelitian ini membuktikan bahwa dengan pemberian aerobic exercise dapat menurunkan secara signifikan lingkar pinggang pada sampel yang memiliki resiko sindrom metabolic.

Lingkar pinggang mempunyai hubungan yang kuat dengan obesitas sentral dan risiko penyakit kardiovaskular, dibandingkan dengan lingkar panggul dan indeks masa tubuh. Lingkar pinggang dapat mendeteksi sindrom metabolik dengan ketepatan yang cukup tinggi. Lemak viseral yang disimpan di dalam abdomen berbahaya karena lemak visceral tersebut paling dekat dengan hepar dan mempunyai rute langsung sirkulasi ke hepar. Sel - sel lemak di dekat hepar cenderung mengirim asam lemak bebas ke hepar dan dapat digunakan untuk sintesis kolesterol. Senam aerobic exercise yang dilakukan secara teratur dengan frekuensi minimal 3 kali/minggu dengan durasi setiap latihan lebih dari 30 menit menyebabkan lipolisis di jaringan adipose sehingga menurunkan lemak tubuh dan lingkar pinggang. ${ }^{27}$

Penelitian ini sejalan dengan Haque et al (2016) mendapatkan hasil ada hubungan antara pengaruh olahraga zumba terhadap lingkar pinggang pada wanita. Penelitian ini menunjukkan bahwa median lingkar pinggang sesudah olahraga zumba dari $80,00 \mathrm{~cm}$ dengan lingkar pinggang paling kecil $72 \mathrm{~cm}$ dan paling besar $105 \mathrm{~cm}$ dan menurun menjadi $75,35 \mathrm{~cm}$ dengan lingkar pinggang paling kecil 68 dan paling besar $101 \mathrm{~cm}$. Terlihat kecenderungan penurunan lingkar pinggang sebesar $4,34 \mathrm{~cm}$ dengan penurunan paling kecil 1,40 $\mathrm{cm}$ dan paling besar penurunan sebesar $6,90 \mathrm{~cm}$.

\section{Pengaruh Aerobic Exercise terhadap tekanan darah pada wanita dewasa yang sindrom metabolic}

Berdasarkan hasil penelitian setelah dilakukan uji statistic T-test dependent pada table 5 didapatkan bahwa ada pengaruh aerobic exercise terhadap tekanan darah (sistolik dan diastolic $\mathrm{p}=0,00)$. Rata-rata tekanan darah sistolik sebelum perlakuan sebesar 133,28 dan diastolic sebesar 87,44 dan setelah perlakuan selama 4 minggu tekanan darah sistolik menurun menjadi 131,58 dan diastolic sebesar 85,44 . Jadi berdasarkan penelitian ini membuktikan bahwa dengan pemberian aerobic exercise dapat menurunkan secara signifikan tekanan darah pada sampel yang memiliki resiko sindrom metabolic.

Senam aerobik dapat merilekskan pembuluh-pembuluh darah penurunan tekanan darah juga dapat terjadi akibat aktivitas memompa jantung berkurang. Otot jantung pada orang yang rutin berolahraga sangat kuat, maka otot jantung dari individu yang rajin berolahraga berkontraksi lebih sedikit dari pada otot jantung orang yang jarang berolahraga untuk memompakan volume darah yang sama. Senam aerobik dapat menyebabkan penurunan denyut jantung maka akan menurunkan cardiac output, yang pada akhirnya menyebabkan penurunan tekanan darah. Peningkatan efisiensi kerja jantung dicerminkan dengan penurunan tekanan sistolik, sedangkan penurunan tahanan perifer dicerminkan dengan penurunan tekanan diastolik 24. 
Senam aerobik dapat melemaskan pembuluh-pembuluh darah, sehingga tekanan darah menurun, sama halnya dengan melebarnya pipa air akan menurunkan tekanan air. Latihan senam aerobik juga dapat menyebabkan aktivitas saraf, reseptor hormon, dan produksi hormon-hormon tertentu menurun. Olahraga aerobik menimbulkan efek seperti: beta blocker yang dapat menenangkan sistem saraf simpatik dan melambatkan denyut jantung. Senam aerobik yang dilakukan akan mengurangi kadar hormon norepinefrin (noradrenalin) dalam tubuh, yakni zat yang dikeluarkan sistem saraf yang dapat menaikkan tekanan darah.

Penelitian ini sejalan dengan Anggraini (2015) mendapatkan hasil bahwa terdapat pengaruh senam aerobik terhadap tekanan darah pada ibu-ibu penderita hipertensi setelah para responden diberi perlakuan yaitu senam aerobic. Hasil pengukuran rerata tekanan darah sistolik responden sebelum senam aerobic yaitu $145.18 \mathrm{mmHg}$ pada ibu-ibu penderita hipertensi dan setelah melakukan senam aerobik selama 4 minggu rerata tekanan darah sistolik yaitu $130.67 \mathrm{mmHg}$. Hasil pengukuran rerata tekanan darah diastolik responden sebelum senam aerobik yaitu $92.60 \mathrm{mmHg}$ pada ibu-ibu penderita hipertensi setelah melakukan senam aerobik selama 4 minggu rerata tekanan darah diastolik yaitu $84.07 \mathrm{mmHg}$.

\section{Pengaruh Aerobic Exercise terhadap kadar gula darah puasa pada wanita dewasa yang sindrom metabolic}

Berdasarkan hasil penelitian setelah dilakukan uji statistic T-test dependent pada table 5 didapatkan bahwa ada pengaruh aerobic exercise terhadap kadar gula darah puasa $(\mathrm{p}=0,00)$. Rata-rata kadar gula darah sebelum perlakuan sebesar 110,52 dan setelah perlakuan selama 4 minggu lingkar pinggang menjadi 107,04. Jadi berdasarkan penelitian ini membuktikan bahwa dengan pemberian aerobic exercise dapat menurunkan secara signifikan kadar gula darah puasa pada sampel yang memiliki resiko sindrom metabolic.

Pengaruh latihan fisik terhadap penurunan kadar gula darah yaitu pada otot-otot yang aktif bergerak tidak diperlukan insulin untuk memasukan glukosa ke dalam sel karena pada otot yang aktif sensitivitas reseptor insulin menjadi meningkat sehingga ambilan glukosa meningkat 7 - 20 kali lipat .28 Mekanisme regulasi ambilan glukosa oleh otot pada waktu aktif bergerak disebabkan oleh Insulin memacu pelepasan muscle activating factor (MAF) pada otot yang sedang bergerak, sehingga menyebabkan ambilan glukosa oleh otot tersebut menjadi bertambah dan ambilan glukosa oleh otot yang tidak berkontraksipun ikut meningkat. Saat ini MAF diduga bradikinin, adanya aksi lokal hormon pada anggota badan yang sedang bergerak yang disebut non supresible insulin like activity (NSILA) yang terdapat pada aliran limfe dan tidak dalam darah anggota badan tersebut, adanya peningkatan penyediaan glukosa dan insulin, karena adanya peningkatan aliran darah kedaerah otot yang aktif bergerak 29.

Dengan latihan fisik yang rutin, maka sel akan terlatih dan lebih sensitive terhadap insulin sehingga asupan glukosa yang dibawa glukosa transporter ke dalam sel meningkat. Aktifitas fisik ini pula yang kemudian menurunkan kadar glukosa puasa pada sampel yang diperiksa 30 .

Penelitian ini sejalan dengan Berawi et al (2013) mendapatkan hasil ada pengaruh yang bermakna antara senam aerobik terhadap kadar glukosa darah puasa pada peserta senam aerobik di Pusat Kebugaran Sonia Bandar Lampung dengan nilai $\mathrm{p}=0,003$. Dari hasil penelitian, didapatkan persentasi rata-rata kadar glukosa darah puasa sebelum melakukan aerobik sebesar 81,66 mg/dl dan kadar glukosa darah puasa setelah melakukan aerobik sebesar $67,81 \mathrm{mg} / \mathrm{dl}$. 


\section{KESIMPULAN}

1. Penelitian ini memperoleh hasil bahwa setelah dilakukannya program aerobic exercise selama 4 minggu pada oberitas yang memiliki resiko sindrom metabolic di dapatkan bahwa :

2. Sebelum diberikan aerobic exercise rata-rata lingkar pinggang sebesar $81,28 \mathrm{~cm}$, tekanan darah sistolik sebesar 133,28 $\mathrm{mmHg}$ dan diastolic sebesar $87,44 \mathrm{mmHg}$ serta kadar gula darah sebesar 110,52 mg/dl.

3. Setelah diberikan aerobic exercise rata-rata lingkar pinggang sebesar $80,56 \mathrm{~cm}$, tekanan darah sistolik sebesar 131,58 $\mathrm{mmHg}$ dan diastolic sebesar $85,44 \mathrm{mmHg}$ serta kadar gula darah sebesar 107,04 mg/dl.

4. Ada pengaruh pemberian aerobic exercise terhadap lingkar pinggang $(\mathrm{p}=0,00)$, tekanan darah $(\mathrm{p}=0,00)$ dan kadar gula darah $(\mathrm{p}=0,00)$

\section{KEPUSTAKAAN}

1. Jafar N. Sindroma Metabolik di Indonesia: Potret Gaya Hidup Masyarakat Perkotaan. Yogyakarta: Penerbit Ombak; 2011.

2. Jing Jing Ren, et al. Nutritional Intervention in the Metabolic Sindrome. Asia Pacific Journal Clinical Nutrition. 2007;16(1):418-21.

3. Fattah M. Sindroma Metabolik Dan Penanda Baru Disfungsi Endotel: Asimetrik Dimetil Arginin (ADMA) Dan High Sensitivity C-Reactive Protein (hsCRP). Jurnal Prodia Diagnostics Educational Services. 2006;1(1):71-78.

4. Grundy, Scott M., et al. Third Report of the National Cholesterol Education Program (NCEP) Expert Panel on
Detection, Evaluation, and Treatment of High Blood Cholesterol in Adults (Adult Treatment Panel III) Final Report. National Cholesterol Education Program; September 2002; U.S. Department Of Health and Human Services: 2002.

5. Ford ES. G, WH., Dietz, WH. Prevalence of the Metabolic Syndrome Among US Adults. Finding From the Third National Health and Nutrition Examination Survey. Journal American Medical Association. 2007;287(3):356359

6. Tjokoprawiro A. Pola Hidup Masa Kini yang Berujung pada Penyakit. The Indonesian Journal of Internal Medicine. 2005;38:160-6.

7. Dwipayana ea. Prevalensi Sindroma Metabolik pada Populasi Penduduk Bali, Indonesia. Jurnal Penyakit Dalam. 2011;12.

8. Adriansjah H, \& Adam, J. Sindroma metabolik; pengertian, epidemiologi dan kriteria diagnosis. Forum Diagnosticum, 4. 2006.

9. Kemenkes RI. Riset Kesehatan Dasar (Riskesdas) $2007 . \quad$ Jakarta: Kementerian Kesehatan; 2008.

10. Kemenkes RI. Riset Kesehatan Dasar (Riskesdas) $2013 . \quad$ Jakarta: Kementerian Kesehatan; 2014

11. Dellios, G. 2005. Epidemiology of metabolic syndrome in Europe. European Society of Cardiology

12. Lakka HM., Laaksonen DE, Lakka TA, Niskanen LK, Kumpusalo E, Tuomilehto J. et.al. Disease Mortality in Middle-aged Men The Metabolic Syndrome and Total and 
Cardiovascular. JAMA. 2002; 288(21):2709-2716

13. Shils ME, Shike M. Modern Nutrition in Health and Disease Tenth Edition. Philadelphia:Lippincott Williams \& Wilkins. 2006 p 1080

14. Sidartawan Soegondo, Reno Gustaviani. Sindrom Metabolik. Dalam : Sudoyo,Aru W, dkk. Buku Ajar Ilmu Penyakit Dalam Jilid III Edisi IV. Jakarta: Pusat Penerbitan Departemen Ilmu Penyakit Dalam FKUI,2006. hal 1871-1872.

15. Widjaya A. 2004. Obesitas dan Sindrom Metabolik. Jurnal Cardiology. 2(4): 116

16. World Health Organization. 2000. Obesity: Preventing and Managing the Global Epidemic. Geneva: WHO.

17. Wirakmono. 2006. Sindrom Metabolik. Jurnal Kedokteran Indonesia. 35(10)

18. IDF. 2005. The IDF Concencus Worldwide Definition of the Metabolic Syndrome. Journal American Medical Association. 213(12): 1345-52

19. Shahab, A. 2007. Sindrom Metabolik. Jurnal media informasi Ilmu Kesehatan dan Kedokteran. 10(4): 2132.

20. Angraeni D. 2007. Mewaspadai Adanya Sindrom Metabolic. Jurnal Kedokteran Indonesia. 25(6): 18-25.

21. Anwar T. 2008. Faktor risiko penyakit jantung koroner.Medan: Fakultas Kedokteran Universitas Sumatera Utara.
22. Supariasa, I.D.N., Bakri, B., Fajar, I., et al. 2002. Penlitian Status Gizi. Jakarta : EGC.

23. Depkes RI. 2007. Laporan Riset Kesehatan Dasar (RISKESDAS). Jakarta : Litbangkes Depkes RI.

24. Harber, P.M., \& Scoot, T. (2009). Aerobic exercise training improves whole muscle and single Myofiber size and function in older woman. Journal Physical Regular Integral Company Physical

25. Nanny Selamiharja. 2015. Hipertensi Terkendali, Stroke Tak Terjadi.

26. Indiyani P, Supriyatno H, Santoso A. 2007. Pengaruh latihan fisik senam aerobik terhadap penurunan kadar gula darah pada penderita $\mathrm{dm}$ tipe 2 di wilayah puskesmas bukateja purbalingga. Media Ners. 1(2):89 - 99

27. Indriati, E., Antropometri Untuk Kedokteran, Keperawatan, Gizi, dan Olahraga. Yogyakarta: Citra Aji Parama, 2009.

28. Indiyani P, Supriyatno H, Santoso A. 2007. Pengaruh latihan fisik senam aerobik terhadap penurunan kadar gula darah pada penderita dm tipe 2 di wilayah puskesmas bukateja purbalingga. Media Ners. 1(2):89 - 99

29. Asdie AH. 1997. Latihan jasmani sebagai terapi pada diabetes melitus. Jakarta.

30. Tortora GJ, Derrickson B. 2011. Principles of anatomy and physiology 13th ed. John Wiley and Sons (Asia) Pte Ltd. Singapore. 
